\title{
Combination therapy for hypertension in patients with CKD: a subanalysis of the Combination Therapy of Hypertension to Prevent Cardiovascular Events trial
}

\author{
Hiromi Rakugi ${ }^{1}$, Toshio Ogihara ${ }^{1,2}$, Seiji Umemoto ${ }^{3}$, Masunori Matsuzaki ${ }^{3}$, Hiroaki Matsuoka ${ }^{4}$, \\ Kazuyuki Shimada ${ }^{5}$, Jitsuo Higaki ${ }^{6}$, Sadayoshi Ito ${ }^{7}$, Akira Kamiya ${ }^{3}$, Hiromichi Suzuki ${ }^{8}$, Yasuo Ohashi ${ }^{9}$, \\ Kazuaki Shimamoto ${ }^{10}$ and Takao Saruta ${ }^{11}$ for the Combination Therapy of Hypertension to Prevent \\ Cardiovascular Events Trial Group
}

The Combination Therapy of Hypertension to Prevent Cardiovascular Events (COPE) trial was a multicenter, randomized, threearm comparative study $(N=3293)$ undertaken to determine the optimal combination therapy, based on the occurrence of cardiovascular events in patients treated with an angiotensin II receptor blocker (ARB), a $\beta$-blocker (BB) or a thiazide diuretic (TD) in addition to the calcium antagonist benidipine as baseline medication. This subanalysis was conducted to compare the efficacy of three combination therapies in a subset of 834 patients with chronic kidney disease (CKD) (287 patients treated with benidpine-ARB, 283 patients treated with benidipine-BB and 264 patients treated with benidipine-TD). The incidence of composite cardiovascular events as the primary end point did not differ among these three groups. The incidence of hard end points and cerebrovascular events among these groups did not differ either, although the incidence among all patients in the COPE trial was lower in the benidipine-TD group than in the benidipine-BB group. The incidence of new-onset diabetes mellitus was higher in the benidipine-TD group than in the benidipine-ARB group among patients with CKD. The estimated glomerular filtration rate (eGFR) was maintained even after 12 months of treatment in patients with a baseline eGFR $<60 \mathrm{ml} \mathrm{min}^{-1}$ per $1.73 \mathrm{~m}^{2}$ regardless of the treatment group, although the eGFR decreased over time in all patients in the three groups. In conclusion, in patients with CKD, all of the tested combination therapies demonstrated comparable efficacy in terms of prevention of cardiovascular events as well as maintenance of eGFR.

Hypertension Research (2013) 36, 947-958; doi:10.1038/hr.2013.63; published online 18 July 2013

Keywords: calcium-channel blocker; chronic kidney disease; combination therapy; glomerular filtration rate; urinary protein

\section{INTRODUCTION}

Chronic kidney disease (CKD) and hypertension are closely related in a vicious cycle; thus, blood pressure (BP) control is extremely important for patients with CKD. Both CKD and hypertension are risk factors for cardiovascular events; ${ }^{1}$ therefore, the aim of BP control in $\mathrm{CKD}$ is to inhibit the progression of $\mathrm{CKD}$, delay worsening of the disease to end-stage kidney disease and inhibit the occurrence of cardiovascular events.

It is well recognized that antihypertensive therapy inhibits cardiovascular events regardless of the presence or absence of CKD. ${ }^{1,2}$ Reducing BP is the most important intervention to delay worsening of CKD as well; it has been shown that renin-angiotensin system blockers have an added effect in patients with advanced nephropathy and albuminuria of $>33.9 \mathrm{mg} \mathrm{mmol}^{-1} .^{3,4}$ However, the superiority of renin-angiotensin system blockers as inhibitors of CKD progression has not been demonstrated in patients with hypertension who have nephropathy and normoalbuminuria or microalbuminuria. ${ }^{5,6}$

A large proportion of patients with hypertension require concomitant use of two or more antihypertensive drugs to achieve the BP target of 130/80 mm Hg. ${ }^{7,8}$ Especially patients with CKD are often refractory to treatment and require concomitant treatment with antihypertensive drugs. ${ }^{9}$ The results of the prespecified secondary

\footnotetext{
${ }^{1}$ Department of Geriatric Medicine and Nephrology, Osaka University Graduate School of Medicine, Suita, Japan; ${ }^{2}$ Morinomiya University of Medical Sciences, Osaka, Japan; ${ }^{3}$ Pharmaceutical Clinical Research Center, Yamaguchi University, Ube, Japan; ${ }^{4}$ Department of Hypertension and Cardiorenal Medicine, Dokkyo Medical University, Mibu, Japan; ${ }^{5}$ Division of Cardiovascular Medicine, Department of Medicine, Jichi Medical University, School of Medicine, Shimotsuke, Japan; ${ }^{6}$ Division of Cardiology, Department of Integrated Medicine and Informatics, Ehime University Graduate School of Medicine, Toon, Japan; 7 Division of Nephrology, Endocrinology and Vascular Medicine, Department of Medicine, Tohoku University School of Medicine, Sendai, Japan; ${ }^{8}$ Department of Nephrology, Saitama Medical University School of Medicine, Iruma, Japan; ${ }^{9}$ Department of Biostatistics, School of Public Health, University of Tokyo, Tokyo, Japan; ${ }^{10}$ Sapporo Medical University School of Medicine, Sapporo, Japan and ${ }^{11}$ Keio University, Tokyo, Japan Correspondence: Professor H Rakugi, Department of Geriatric Medicine and Nephrology, Osaka University Graduate School of Medicine, 2-2 Yamadaoka, B6, Suita 565-0871, Japan. 
analysis of the avoiding cardiovascular events through combination therapy in patients living with systolic hypertension (ACCOMPLISH) trial showed that concomitant use of an ACE inhibitor and a $\mathrm{Ca}$ antagonist in patients with CKD contributed to maintain their estimated glomerular filtration rate (eGFR) more effectively than concomitant use of an ACE inhibitor and a diuretic drug. ${ }^{10}$ However, it is not clear what types of antihypertensive drugs would effectively prevent the occurrence of cardiovascular events while maintaining the renal function of hypertensive patients with $\mathrm{CKD}$ when a $\mathrm{Ca}$ antagonist is used as the basal agent.

Benidipine is a long-acting dihydropyridine $\mathrm{Ca}$ antagonist; it is known that benidipine inhibits not only L-type Ca channels but also $\mathrm{N}$ - and T-type Ca channels and dilates renal afferent and efferent arterioles. ${ }^{11,12}$ It has been reported that benidipine decreases the level of urinary protein in patients with CKD more significantly than L-type Ca antagonists. ${ }^{13,14}$ Benidipine has also been reported to be superior to L-type Ca antagonists regarding prevention of events due to $\mathrm{CKD}$ progression, and may be more effective in maintaining eGFR. ${ }^{15}$

Using the prospective, randomized, open-label, blinded endpoint (PROBE) method, the COPE trial aimed at finding the optimal drug for concomitant use with calcium-channel blocker benidipine in the treatment of hypertension. ${ }^{16}$ It has been reported that the rate of achievement of the BP target and the prevention of cardiovascular events as the primary results were similar among benidipine-thiazide diuretic (TD), benidipine-angiotensin receptor blocker (ARB) and benidipine- $\beta$-blocker (BB) subgroups. In the secondary analysis, however, it was suggested that the benidipine-BB therapy was inferior to benidipine-TD therapy in hard end points and prevention of stroke, and inferior to benidipine$A R B$ therapy regarding prevention of new-onset diabetes. In the subanalysis of elderly people 65 years or older, similar findings were observed; namely, the occurrence of stroke was higher in the benidipine- $\mathrm{BB}$ group than in the benidipine-TD group, and that new-onset diabetes was higher than the occurrence in the benidipineARB group. ${ }^{17}$

The aim of the present subanalysis of the COPE trial is to determine what types of antihypertensive drugs can prevent the occurrence of cardiovascular events and at the same time contribute to the maintenance of renal function in patients with CKD.

\section{METHODS}

\section{Study design, setting and participants}

The COPE trial was an investigator-initiated multicenter study with PROBE design that compared cardiovascular effects and achievement of target BP $(<140 / 90 \mathrm{~mm} \mathrm{Hg}$ ) with three dihydropyridine calcium-channel blocker (ARB, $\mathrm{BB}$ or TD) benidipine-based regimens in 3501 hypertensive patients who did not achieve the target BP with benidipine alone at the dose of $4 \mathrm{mg}$ per day. ${ }^{16,17}$

The rationale and design, trial management and the main results of the COPE trial have already been reported. ${ }^{16,17}$ In brief, participants with a sitting systolic BP of $\geqslant 140 \mathrm{~mm} \mathrm{Hg}$ or a diastolic BP of $\geqslant 90 \mathrm{~mm} \mathrm{Hg}$, or both if untreated, or whatever the treatment, were men and women aged 40-85 years who did not achieve the target $\mathrm{BP}(<140 / 90 \mathrm{~mm} \mathrm{Hg})$ in the sitting position at a clinic after monotherapy with benidipine $4 \mathrm{mg}$ per day during the run-in phase (4-8 weeks). These patients were randomly assigned to receive benidipine combined with an ARB, a BB or a TD. After the randomization, all patients were followed up for at least 3 years until the trial was terminated. The BP-management titration algorithm, together with other details of the study design, were as described previously. ${ }^{16,17}$ At each follow-up visit, we obtained information about any suspected composite end point or adverse event. The median follow-up was 3.6 years. ${ }^{17}$

\section{Outcome measures}

A prespecified post-hoc analysis was made to compare the cardiovascular effects of benidipine-based combination regimens (benidipine-ARB vs. benidipine-BB vs. benidipine-TD) in patients with CKD and patients without CKD. The definition of CKD is an eGFR $<60 \mathrm{ml}$ per minute per $1.73 \mathrm{~m}^{2}$ or presence of urinary protein. Serum creatinine values were evaluated in all patients at the pre-randomization visit and every 6 months. Urinary protein was assessed by the qualitative dipstick method. eGFR was estimated using a modified MDRD formula adapted for the Japanese population. ${ }^{18}$

The evaluated end points were consistent with the original trial design and included the primary and secondary end points of the COPE trial. ${ }^{16} \mathrm{Co}-$ primary end points: composite of cardiovascular morbidity and mortality (sudden death, fatal or non-fatal stroke, fatal or non-fatal myocardial infarction, hospitalization due to unstable angina, new onset of heart failure (New York Heart Association class II-IV), new onset or worsening of peripheral arterial disease and renal events defined as serum creatinine level doubled to over $2 \mathrm{mg} \mathrm{dl}^{-1}$, serum creatinine $\geqslant 4.0 \mathrm{mg} \mathrm{dl}^{-1}$, or renal dialysis), and achievement of target BP $(<140 / 90 \mathrm{~mm} \mathrm{Hg})$. Secondary end points are as follows: all-cause mortality, hard composite cardiovascular events (cardiovascular death, non-fatal myocardial infarction and non-fatal stroke excluding transient ischemic attack), new onset of diabetes and adverse events.

\section{Statistical methods}

In total, 3293 patients who were prescribed a combination treatment (1110 patients treated with benidipine-ARB, 1089 patients treated with benidipineBB and 1094 patients treated treated with benidipine-TD) were compared in the two groups with full set analysis to specifically evaluate benidipine-based combination therapy for the elderly in the COPE trial. ${ }^{17}$ Patient characteristics were reported as the mean \pm s.d. or percentage. Continuous variables were compared using Student's $t$-test or one-way analysis of variance, as appropriate. Categorical variables were compared using the $\chi^{2}$-test. Blood pressure profiles were compared by analysis of variance for longitudinal data. Hazard ratios were compared using log-rank test. Confidence intervals were calculated using Cox proportional hazards model. The proportion of patients who reported adverse events was also compared using $\chi^{2}$-test. eGFR profiles were compared by analysis of variance for longitudinal data. Comparisons of all time points with baseline were performed using Dunnett's test. Baseline and end of the treatment-phase urinary protein-positive rates were compared using McNemar's test. The differences among the groups were analyzed using Steel-Dwass's test. All data were analyzed using SAS System Release 9.1 (SAS Institute, Cary, NC, USA). All reported $P$-values are two-sided.

\section{RESULTS}

A total of 4790 patients were assessed for eligibility, and 3501 patients were randomly assigned to the benidipine-ARB $(n=1167)$, benidipine-BB $(n=1166)$ or benidipine-TD $(n=1168)$ group. Each group was stratified into the following subgroups: $\mathrm{CKD}$, non-CKD and unknown (Figure 1). The group of patients stratified into unknown included the following: 471 patients with eGFR $\geqslant 60 \mathrm{ml} \mathrm{min}^{-1}$ per $1.73 \mathrm{~m}^{2}$ and unknown urinary protein status, 1 patient with unknown eGFR status and negative urinary protein and 1 patient with unknown eGFR status and unknown urinary protein status.

Demographic and baseline characteristics of patients from the COPE trial are shown in Table 1. Among the 3293 patients in the COPE trial, 834 patients (25.3\%) had CKD, 1986 patients $(60.3 \%)$ did not have CKD and 473 patients $(14.3 \%)$ were in the unknown subgroup. In both the $\mathrm{CKD}$ and non-CKD subgroups, baseline characteristics matched well among those randomized to the three regimens.

At baseline, the mean eGFR of the CKD subgroup was $58.7 \pm 15.2 \mathrm{ml} \mathrm{min}^{-1}$ per $1.73 \mathrm{~m}^{2}$ and the non-CKD subgroup was $79.1 \pm 13.7 \mathrm{ml} \mathrm{min}^{-1}$ per $1.73 \mathrm{~m}^{2}$. Systolic BP in the CKD subgroup was higher at baseline (mean: $155.3 \pm 11.9 \mathrm{~mm} \mathrm{Hg}$ in the CKD subgroup and $153.5 \pm 11.4 \mathrm{~mm} \mathrm{Hg}$ in the non-CKD subgroup), and 


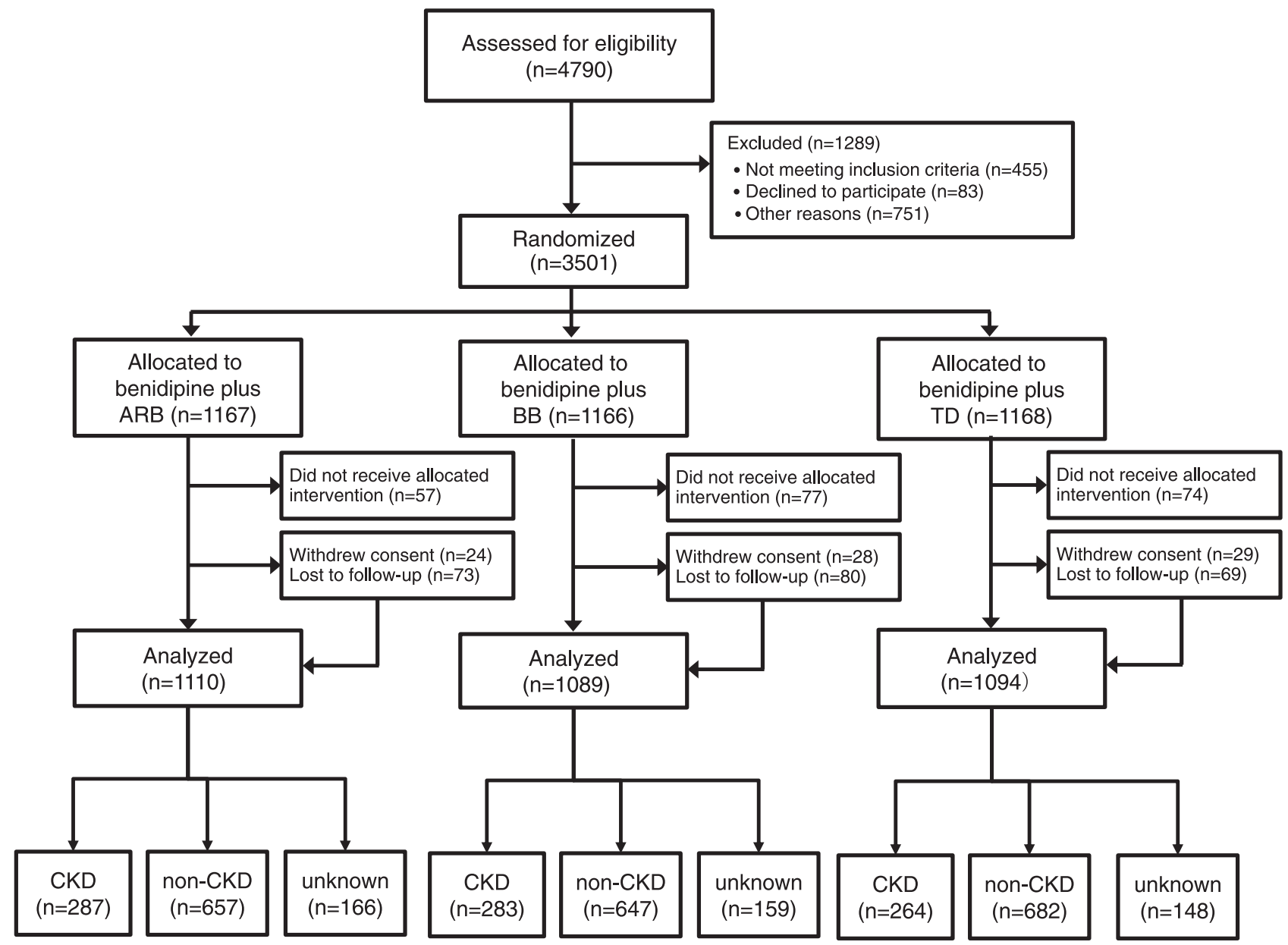

Figure 1 Flowchart of the progress through the phases of this parallel randomized trial of three groups. After randomization, patients who discontinued the trial without receiving the combination treatment were excluded from all analyses to specifically analyze the effects of calcium-channel blocker-based combination therapy for hypertension. ARB, angiotensin receptor blocker; BB, $\beta$-blocker; CKD, chronic kidney disease; TD, thiazide diuretic.

the CKD subgroup had a higher heart rate $(74.7 \pm 11.5$ vs. $73.7 \pm 11.0$ b.p.m.). The CKD subgroup had higher rates of previous cardiovascular disease $(18.5 \%$ vs. $9.5 \%)$, which were mainly stroke $(4.3 \%$ vs. $1.9 \%)$ and angina pectoris $(4.8 \%$ vs. $2.0 \%)$, diabetes $(17.1 \%$ vs. $13.9 \%)$, reported taking more prophylactic antiplatelet agents (11.0\% vs. $6.0 \%)$, statins as lipid-lowering agents (19.3\% vs. $15.4 \%)$ and antidiabetic agents $(9.2 \%$ vs. $6.8 \%)$, than the non-CKD subgroup.

In both the CKD and non-CKD subgroups, there was no significant difference in the change in BP among the three treatment groups (Figure 2). The rate of achievement of the BP target of $<140 /$ $90 \mathrm{~mm} \mathrm{Hg}$ was $63.7 \%$ in the CKD subgroup and $66.3 \%$ in the nonCKD subgroup, showing no significant difference. The rate of achievement with the benidipine-ARB, benidipine- $\mathrm{BB}$ and benidipine-TD therapies was $61.7 \%, 65.8 \%$, and $63.6 \%$, respectively, in the CKD subgroup and $64.6 \%, 66.2 \%$, and $68.1 \%$, respectively, in the non-CKD subgroup, showing no difference among the three therapies in the two subgroups.

\section{Cardiovascular outcomes}

Table 2 shows the incidence of the primary cardiovascular composite end point and secondary end points in the benidipine-ARB, benidipine-BB and benidipine-TD groups. The incidence of the primary cardiovascular composite end point in the CKD subgroup was higher than in the non-CKD subgroup (13.8 vs. 8.1 per 1000 person-years).

As shown in Figure 3, the hazard ratio for new-onset diabetes was significantly lower in the benidipine-ARB group than in the benidipine-TD group.

In the non-CKD subgroup, the hazard ratio for cardiovascular hard composite end points was significantly lower in the benidipine-TD group than in the benidipine-BB group. The hazard ratio for fatal and non-fatal stroke was significantly lower in the benidipine-ARB group than in the benidipine-BB group.

\section{Safety}

Table 3 shows the adverse events found in the COPE trial. Overall, patients with CKD reported more adverse events than patients without CKD. Hyperuricemia, hyperkalemia and blood creatinine increases were more frequent in patients with CKD than in patients without CKD. Furthermore, in both the CKD and non-CKD subgroups, hyperuricemia was more frequently reported in the benidipine-TD groups. On the other hand, bradycardia was more frequent in the benidipine- $\mathrm{BB}$ groups compared with the other benidipine-based combinations in both CKD and non-CKD patients. Hypokalemia and alanine aminotranferase increases were more frequently reported in the benidipine-TD group than in the other 


\begin{tabular}{|c|c|c|c|c|c|c|c|c|c|}
\hline & \multicolumn{4}{|c|}{ Patients with $C K D$} & \multicolumn{4}{|c|}{ Patients without $C K D$} & \multirow{2}{*}{$\begin{array}{c}C K D \text { vs. } \\
\text { non- } C K D \\
\text { P-value }\end{array}$} \\
\hline & $\begin{array}{c}B e n i+A R B \\
(\mathrm{n}=287)\end{array}$ & $\begin{array}{c}B e n i+B B \\
(\mathrm{n}=283)\end{array}$ & $\begin{array}{l}\text { Beni+TD } \\
(\mathrm{n}=264)\end{array}$ & P-value & $\begin{array}{c}B e n i+A R B \\
(\mathrm{n}=657)\end{array}$ & $\begin{array}{c}\text { Beni }+ \text { BB } \\
(\mathrm{n}=647)\end{array}$ & $\begin{array}{l}\text { Beni+TD } \\
(\mathrm{n}=682)\end{array}$ & P-value & \\
\hline \multicolumn{10}{|l|}{ Demographics } \\
\hline Sex, male & $152(53.0)$ & $146(51.6)$ & $139(52.7)$ & 0.943 & $339(51.6)$ & $336(51.9)$ & $345(50.6)$ & 0.877 & 0.614 \\
\hline Age, years & $66.1 \pm 10.7$ & $66.9 \pm 10.4$ & $66.3 \pm 10.8$ & 0.583 & $61.8 \pm 10.3$ & $61.5 \pm 10.5$ & $61.7 \pm 10.6$ & 0.896 & $<0.001$ \\
\hline Body mass index, $\mathrm{kg} \mathrm{m}^{-2}$ & $24.9 \pm 3.5$ & $24.6 \pm 3.5$ & $24.5 \pm 3.4$ & 0.381 & $24.5 \pm 3.3$ & $24.7 \pm 3.4$ & $24.4 \pm 3.4$ & 0.444 & 0.320 \\
\hline Systolic BP, mm Hg & $155.3 \pm 12.0$ & $155.9 \pm 11.4$ & $154.6 \pm 12.4$ & 0.465 & $153.6 \pm 11.7$ & $152.9 \pm 10.7$ & $154.0 \pm 11.8$ & 0.197 & $<0.001$ \\
\hline Diastolic BP, mm Hg & $88.7 \pm 10.5$ & $88.4 \pm 9.9$ & $87.9 \pm 9.9$ & 0.662 & $89.2 \pm 9.4$ & $88.6 \pm 9.7$ & $88.9 \pm 9.9$ & 0.513 & 0.162 \\
\hline Heart rate, b.p.m. & $74.7 \pm 10.8$ & $75.3 \pm 12.2$ & $74.0 \pm 11.5$ & 0.444 & $73.6 \pm 11.1$ & $73.3 \pm 10.5$ & $74.1 \pm 11.3$ & 0.480 & 0.040 \\
\hline $\begin{array}{l}\text { eGFR, } \mathrm{ml} \mathrm{min}^{-1} \\
\text { per } 1.73 \mathrm{~m}^{2}\end{array}$ & $58.6 \pm 16.2$ & $58.9 \pm 15.5$ & $58.4 \pm 13.9$ & 0.709 & $79.2 \pm 13.7$ & $79.5 \pm 13.5$ & $78.7 \pm 13.9$ & 0.937 & $<0.001$ \\
\hline $\begin{array}{l}\text { Urinary protein-positive, } \\
n(\%)\end{array}$ & $101(35.2)$ & $107(37.8)$ & $94(35.6)$ & 0.453 & $0(0)$ & $0(0)$ & $0(0)$ & - & $<0.001$ \\
\hline \multicolumn{10}{|l|}{ Risk factors } \\
\hline $\begin{array}{l}\text { Previous cardiovascular } \\
\text { disease }\end{array}$ & $58(20.2)$ & $47(16.6)$ & $49(18.6)$ & 0.541 & $62(9.4)$ & $59(9.1)$ & $68(10.0)$ & 0.866 & $<0.001$ \\
\hline Stroke & $16(5.6)$ & $9(3.2)$ & $11(4.2)$ & 0.368 & $14(2.1)$ & $12(1.9)$ & $11(1.6)$ & 0.782 & $<0.001$ \\
\hline Angina pectoris & $16(5.6)$ & $13(4.6)$ & $11(4.2)$ & 0.728 & $12(1.8)$ & $14(2.2)$ & $13(1.9)$ & 0.900 & $<0.001$ \\
\hline Myocardial infarction & $6(2.1)$ & $3(1.1)$ & $2(0.8)$ & 0.350 & $4(0.6)$ & $3(0.5)$ & $4(0.6)$ & 0.930 & 0.035 \\
\hline Diabetes & $50(17.4)$ & $52(18.4)$ & $41(15.5)$ & 0.670 & $90(13.7)$ & $90(13.9)$ & $97(14.2)$ & 0.962 & 0.029 \\
\hline Dyslipidemia & $117(40.8)$ & $123(43.5)$ & $113(42.8)$ & 0.794 & $255(38.8)$ & $238(36.8)$ & $284(41.6)$ & 0.189 & 0.113 \\
\hline Current smoking & $181(63.1)$ & $170(60.1)$ & $161(61.0)$ & 0.753 & $265(40.3)$ & $272(42.0)$ & $276(40.5)$ & 0.784 & 0.250 \\
\hline \multicolumn{10}{|l|}{ Previous medication } \\
\hline Antihypertensive agents & $230(80.1)$ & $220(77.7)$ & $218(82.6)$ & 0.367 & $529(80.5)$ & $523(80.8)$ & $534(78.3)$ & 0.451 & 0.886 \\
\hline Benidipine & $172(59.9)$ & $182(64.3)$ & $167(63.3)$ & 0.530 & $430(65.4)$ & $421(65.1)$ & $442(64.8)$ & 0.970 & 0.182 \\
\hline Other CCB & 37 (12.9) & $23(8.1)$ & $40(15.2)$ & 0.035 & 69 (10.5) & $68(10.5)$ & $64(9.4)$ & 0.734 & 0.142 \\
\hline ARB & $31(10.8)$ & $33(11.7)$ & $25(9.5)$ & 0.706 & $51(7.8)$ & $53(8.2)$ & $50(7.3)$ & 0.842 & 0.012 \\
\hline ACE inhibitor & $8(2.8)$ & $12(4.2)$ & $8(3.0)$ & 0.483 & $8(1.2)$ & $14(2.2)$ & $14(2.1)$ & 0.569 & 0.125 \\
\hline $\mathrm{BB}$ & $7(2.4)$ & $2(0.7)$ & $7(2.7)$ & 0.590 & $5(0.8)$ & $4(0.6)$ & $6(0.9)$ & 0.372 & 0.012 \\
\hline Diuretics & $9(3.1)$ & $5(1.8)$ & $5(1.9)$ & 0.185 & $9(1.4)$ & 12 (1.9) & $8(1.2)$ & 0.859 & 0.007 \\
\hline Others & $4(1.4)$ & $1(0.4)$ & $2(0.8)$ & 0.390 & $4(0.6)$ & $8(1.2)$ & $0(0.0)$ & 0.015 & 0.486 \\
\hline \multicolumn{10}{|l|}{ Concomitant medication } \\
\hline Antiplatelet agents & $38(13.2)$ & $28(9.9)$ & $26(9.8)$ & 0.337 & $51(7.8)$ & $32(4.9)$ & $36(5.3)$ & 0.063 & $<0.001$ \\
\hline Statins & $60(20.9)$ & $58(20.5)$ & $43(16.3)$ & 0.321 & $99(15.1)$ & $102(15.8)$ & $104(15.2)$ & 0.937 & 0.010 \\
\hline Antidiabetic agents & $27(9.4)$ & $29(10.2)$ & $21(8.0)$ & 0.646 & $42(6.4)$ & $46(7.1)$ & $48(7.0)$ & 0.851 & 0.029 \\
\hline
\end{tabular}

Abbreviations: ACE, angiotensin-converting enzyme; ARB, angiotensin receptor blocker; BB, $\beta$-blocker; Beni, benidipine; BP, blood pressure; CCB, calcium-channel blocker; CKD, chronic kidney disease; TD, thiazide diuretic.

Data are shown as number of patients $(\%)$ or mean \pm s.d.

treatment groups of only the non-CKD subgroup. Hyperkalemia was more frequent only in the benidipine-ARB group of the $\mathrm{CKD}$ subgroup. There were no significant differences among the three regimens concerning serious adverse events in the CKD and nonCKD subgroups (Supplementary data).

\section{Renal function}

Regardless of the presence or absence of CKD, eGFR in the benidipine-ARB, benidipine-BB and benidipine-TD groups decreased from $74.0 \pm 17.1,74.2 \pm 17.1$ and $74.0 \pm 16.7 \mathrm{ml} \mathrm{min}^{-1}$ per $1.73 \mathrm{~m}^{2}$, respectively, at baseline to $71.5 \pm 17.3, \quad 72.5 \pm 17.6$ and $71.2 \pm 17.0 \mathrm{ml} \mathrm{min}^{-1}$ per $1.73 \mathrm{~m}^{2}$, respectively, at the end of the treatment phase, showing no significant difference among the treatment groups. Table 4 shows the baseline characteristics of the group positive for urinary protein and the group negative for urinary protein among the patients with eGFR values $\geqslant 60$ and $<60 \mathrm{ml} \mathrm{min}^{-1}$ per $1.73 \mathrm{~m}^{2}$, respectively, and Figure 4 shows the changes in eGFR. The incidence of the primary cardiovascular composite end point was higher in the group of patients positive for urinary protein than in the group of those negative for urinary protein in both the group with eGFR levels $\geqslant 60 \mathrm{ml} \mathrm{min}^{-1}$ per $1.73 \mathrm{~m}^{2}$ (13.4 vs. 8.1 per 1000 person-years, $P=0.147$ ) and the group with eGFR levels $<60 \mathrm{ml} \mathrm{min}^{-1}$ per $1.73 \mathrm{~m}^{2}$ (19.2 vs. 10.9 per 1000 person-years, $P=0.234$ ), although these differences were not significant.

As shown in Figure 4, for the group of patients with a baseline eGFR $\geqslant 60 \mathrm{ml} \mathrm{min}^{-1}$ per $1.73 \mathrm{~m}^{2}$, eGFR decreased from $79.4 \pm 14.0$, $79.6 \pm 14.1$ and $78.8 \pm 14.2 \mathrm{ml} \mathrm{min}^{-1}$ per $1.73 \mathrm{~m}^{2}$, respectively, at baseline to $75.8 \pm 15.2,76.4 \pm 16.0$ and $75.0 \pm 15.2 \mathrm{ml} \mathrm{min}^{-1}$ per $1.73 \mathrm{~m}^{2}$, respectively, at the end of the treatment phase, showing no 
Patients with CKD

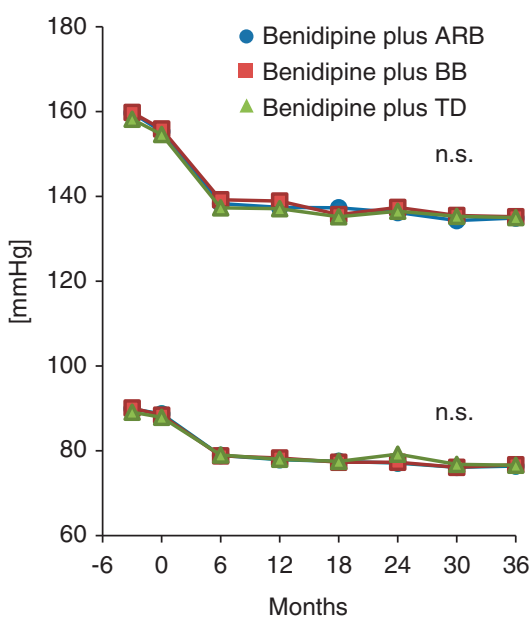

Patients without CKD

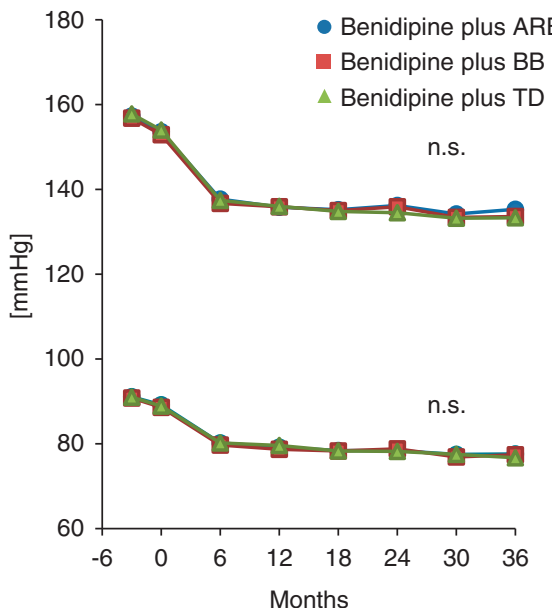

Figure 2 Effects of treatment on mean systolic blood pressure (SBP) and diastolic blood pressure (DBP) over time by group. ARB, angiotensin receptor blocker; BB, $\beta$-blocker; CKD, chronic kidney disease; n.s., not significant; TD, thiazide diuretic.

Table 2 Incidence of primary and secondary end points among patients with CKD and patients without CKD

\begin{tabular}{|c|c|c|c|c|c|c|c|c|c|}
\hline & $\begin{array}{c}B e n i+A R B \\
(\mathrm{n}=287)\end{array}$ & $\begin{array}{c}\text { Beni+BB } \\
(\mathrm{n}=283)\end{array}$ & $\begin{array}{l}\text { Beni+TD } \\
(\mathrm{n}=264)\end{array}$ & $\mathrm{P}$-value & $\begin{array}{c}\text { Beni }+ \text { ARB } \\
(\mathrm{n}=657)\end{array}$ & $\begin{array}{c}B e n i+B B \\
(\mathrm{n}=647)\end{array}$ & $\begin{array}{l}\text { Beni+TD } \\
(\mathrm{n}=682)\end{array}$ & P-value & $\begin{array}{c}\text { Patients with } \\
C K D \text { vs. } \\
\text { without } C K D \\
\text { P-value }\end{array}$ \\
\hline \multicolumn{10}{|l|}{ Primary end points } \\
\hline Incidence number & 15 & 13 & 13 & & 17 & 24 & 17 & & \\
\hline \multicolumn{10}{|c|}{ Secondary end points } \\
\hline \multicolumn{10}{|c|}{ Cardiovascular hard composite end points } \\
\hline Incidence number & 9 & 8 & 7 & & 11 & 17 & 7 & & \\
\hline $\begin{array}{l}\text { Per } 1000 \text { person- } \\
\text { years }\end{array}$ & 8.6 & 8.1 & 7.2 & 0.941 & 4.6 & 7.3 & 2.8 & 0.079 & 0.058 \\
\hline \multicolumn{10}{|l|}{ All-cause mortality } \\
\hline Incidence number & 7 & 8 & 9 & & 11 & 9 & 12 & & \\
\hline $\begin{array}{l}\text { Per } 1000 \text { person- } \\
\text { years }\end{array}$ & 6.6 & 7.9 & 9.2 & 0.803 & 4.6 & 3.8 & 4.8 & 0.849 & 0.031 \\
\hline \multicolumn{10}{|l|}{ New-onset diabetes } \\
\hline Incidence number & 3 & 10 & 12 & & 13 & 22 & 15 & & \\
\hline $\begin{array}{l}\text { Per } 1000 \text { person- } \\
\text { years }\end{array}$ & 2.8 & 10.1 & 12.7 & 0.043 & 5.4 & 9.6 & 6.1 & 0.183 & 0.466 \\
\hline
\end{tabular}

Abbreviations: ARB, angiotensin receptor blocker; BB, $\beta$-blocker; Beni, benidipine; CKD, chronic kidney disease; TD, thiazide diuretic.

Differences in the incidence of primary and secondary cardiovascular events, all-cause mortality and new-onset diabetes among the three groups and between patients with CKD and patients without CKD were compared using log-rank test. 


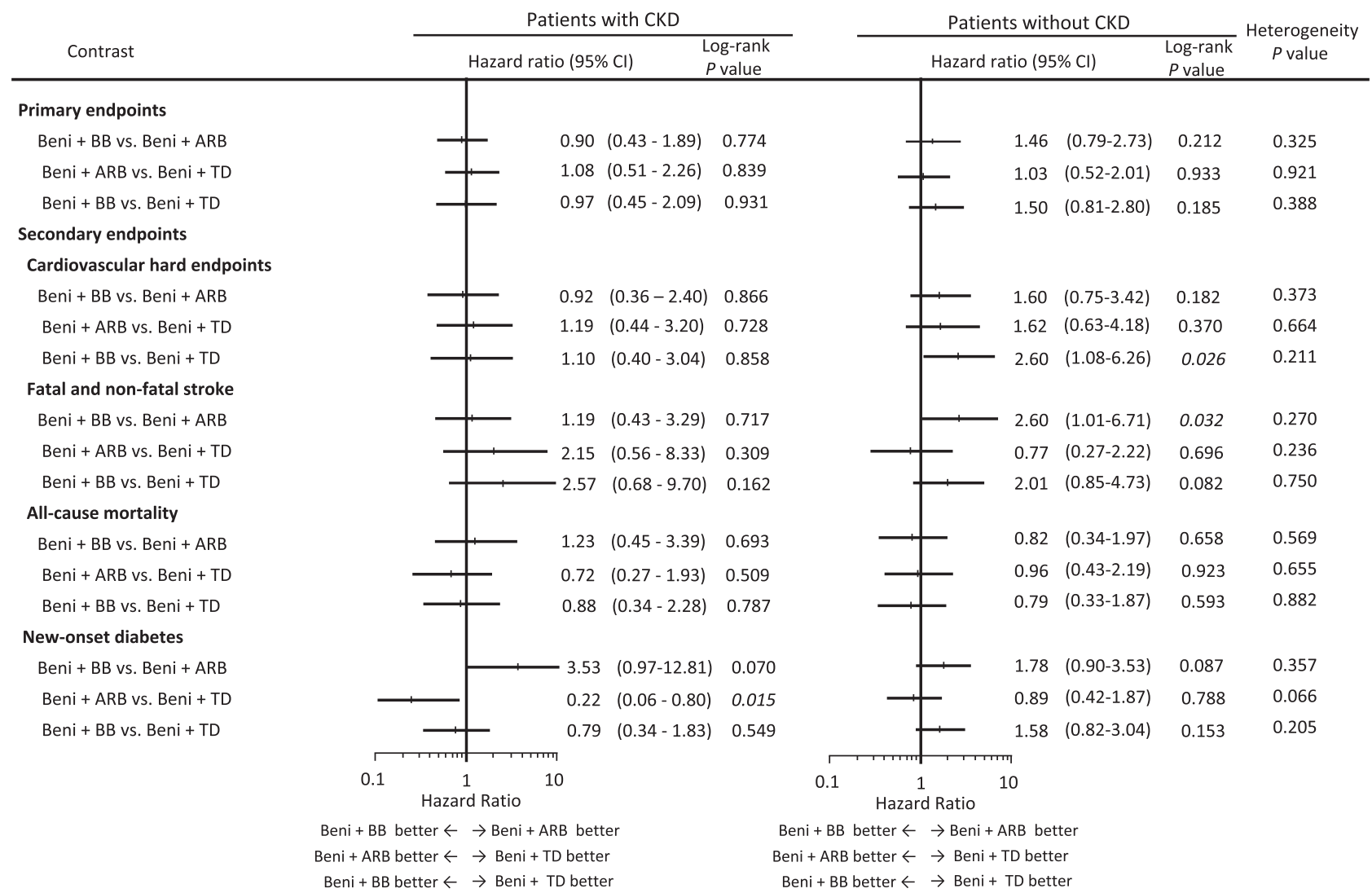

Figure 3 Hazard ratios for primary and secondary end points: cardiovascular hard end points, fatal and non-fatal stroke and new-onset diabetes in the two groups and three treatment groups. Cardiovascular hard composite end points consisted of cardiovascular death, fatal or non-fatal myocardial infarction and stroke excluding transient ischemic attack. ARB, angiotensin receptor blocker; BB, $\beta$-blocker; Beni, benidipine; CKD, chronic kidney disease; TD, thiazide diuretic.

Table 3 Adverse events

\begin{tabular}{|c|c|c|c|c|c|c|c|c|c|c|c|}
\hline & \multicolumn{5}{|c|}{ Patients with CKD $(\mathrm{n}=834)$} & \multicolumn{5}{|c|}{ Patients without CKD $(\mathrm{n}=1996)$} & \multirow{2}{*}{$\begin{array}{c}\text { Patients } \\
\text { with CKD } \\
\text { vs. without } \\
C K D \\
\text { P-value }\end{array}$} \\
\hline & $\begin{array}{c}B e n i+A R B \\
(\mathrm{n}=287)\end{array}$ & $\begin{array}{l}\text { Beni+BB } \\
(\mathrm{n}=283)\end{array}$ & $\begin{array}{l}\text { Beni+TD } \\
(\mathrm{n}=264)\end{array}$ & P-value & Total & $\begin{array}{c}B e n i+A R B \\
(\mathrm{n}=657)\end{array}$ & $\begin{array}{c}\text { Beni+BB } \\
(\mathrm{n}=647)\end{array}$ & $\begin{array}{l}\text { Beni+TD } \\
(\mathrm{n}=682)\end{array}$ & P-value & Total & \\
\hline \multicolumn{12}{|c|}{ Common adverse events in the COPE tria ${ }^{\beta}$} \\
\hline Hyperuricemia & $10(3.5 \%)$ & $4(1.4 \%)$ & $28(10.6 \%)$ & $<0.001$ & $42(5.0 \%)$ & $7(1.1 \%)$ & $12(1.9 \%)$ & $47(6.9 \%)$ & $<0.001$ & $66(3.3 \%)$ & 0.031 \\
\hline Hypokalemia & $1(0.3 \%)$ & $1(0.4 \%)$ & $5(1.9 \%)$ & 0.076 & $7(0.8 \%)$ & $5(0.8 \%)$ & $0(0.0 \%)$ & $20(2.9 \%)$ & $<0.001$ & $25(1.3 \%)$ & 0.337 \\
\hline Hyperkalemia & $8(2.8 \%)$ & $1(0.4 \%)$ & $1(0.4 \%)$ & 0.009 & $10(1.2 \%)$ & $3(0.5 \%)$ & $5(0.8 \%)$ & $2(0.3 \%)$ & 0.457 & $10(0.5 \%)$ & 0.045 \\
\hline $\begin{array}{l}\text { Blood creati- } \\
\text { nine increased }\end{array}$ & $7(2.4 \%)$ & $5(1.8 \%)$ & $13(4.9 \%)$ & 0.076 & $25(3.0 \%)$ & $1(0.2 \%)$ & $1(0.2 \%)$ & $5(0.7 \%)$ & 0.117 & $7(0.4 \%)$ & $<0.001$ \\
\hline ALT increased & 7 (2.4\%) & $8(2.8 \%)$ & $8(3.0 \%)$ & 0.911 & $23(2.8 \%)$ & $20(3.0 \%)$ & $7(1.1 \%)$ & 25 (3.7\%) & 0.009 & $52(2.6 \%)$ & 0.834 \\
\hline Vertigo & $0(0.0 \%)$ & 7 (2.5\%) & $4(1.5 \%)$ & 0.033 & $11(1.3 \%)$ & $4(0.6 \%)$ & 9 (1.4\%) & 12 (1.8\%) & 0.157 & 25 (1.3\%) & 0.897 \\
\hline Bradycardia & $0(0.0 \%)$ & $9(3.2 \%)$ & $0(0.0 \%)$ & $<0.001$ & $9(1.1 \%)$ & $3(0.5 \%)$ & $32(4.9 \%)$ & $1(0.1 \%)$ & $<0.001$ & $36(1.8 \%)$ & 0.156 \\
\hline Overall & $152(53.0 \%)$ & $131(46.3 \%)$ & $144(54.5 \%)$ & 0.118 & $427(51.2 \%)$ & $279(42.5 \%)$ & $290(44.8 \%)$ & $310(45.5 \%)$ & 0.513 & $879(44.3 \%)$ & $<0.001$ \\
\hline
\end{tabular}

Abbreviations: ALT, alanine aminotransferase; ARB, angiotensin receptor blocker; BB, $\beta$-blocker; Beni, benidipine; CKD, chronic kidney disease; TD, thiazide diuretic. Data are shown as number of patients (\%).

${ }^{a}$ Adverse events shown in the table were previously reported.

significant difference among the treatment groups. For the group of patients with a baseline eGFR $<60 \mathrm{ml} \mathrm{min}^{-1}$ per $1.73 \mathrm{~m}^{2}$, on the other hand, eGFR showed a small increase from $51.3 \pm 7.3,51.5 \pm 6.6$ and $51.9 \pm 6.9 \mathrm{ml} \mathrm{min}^{-1}$ per $1.73 \mathrm{~m}^{2}$, respectively, at baseline to
$54.4 \pm 14.4,54.9 \pm 13.4$ and $54.2 \pm 13.5 \mathrm{ml} \mathrm{min}^{-1}$ per $1.73 \mathrm{~m}^{2}$, respectively, at the end of the treatment phase.

For the group of patients with a baseline eGFR $\geqslant 60 \mathrm{ml} \mathrm{min}^{-1}$ per $1.73 \mathrm{~m}^{2}$, a significant decrease in eGFR was observed in the 


\begin{tabular}{|c|c|c|c|c|c|c|c|c|c|}
\hline & \multicolumn{4}{|c|}{ Baseline eGFR $\geqslant 60 \mathrm{~m} / \mathrm{min}^{-1}$ per $1.73 \mathrm{~m}^{2}$} & \multicolumn{4}{|c|}{ Baseline eGFR $<60 \mathrm{~m} / \mathrm{min}^{-1}$ per $1.73 \mathrm{~m}^{2}$} & \multirow[b]{2}{*}{ P-value } \\
\hline & $\begin{array}{c}\text { All } \\
(\mathrm{n}=2672)\end{array}$ & $\begin{array}{l}\text { UP-positive } \\
(\mathrm{n}=215)\end{array}$ & $\begin{array}{l}\text { UP-negative } \\
(\mathrm{n}=1986)\end{array}$ & P-value a & $A / /(\mathrm{n}=618)$ & $\begin{array}{l}\text { UP-positive } \\
\quad(\mathrm{n}=86)\end{array}$ & $\begin{array}{c}\text { UP-negative } \\
(n=423)\end{array}$ & P-value $e^{a}$ & \\
\hline \multicolumn{10}{|l|}{ Demographics } \\
\hline Sex, male & $1362(51.0)$ & $131(60.9)$ & $1020(51.4)$ & 0.008 & 306 (49.5\%) & $57(66.3)$ & $203(48.0)$ & 0.002 & 0.513 \\
\hline Age, years & $61.9 \pm 10.6$ & $61.8 \pm 11.0$ & $61.7 \pm 10.5$ & 0.869 & $68.1 \pm 10.0$ & $65.2 \pm 11.0$ & $68.0 \pm 9.7$ & 0.020 & $<0.001$ \\
\hline Diastolic BP, mm Hg & $89.0 \pm 9.7$ & $89.7 \pm 10.2$ & $88.9 \pm 9.7$ & 0.259 & $87.9 \pm 10.1$ & $89.0 \pm 11.8$ & $87.3 \pm 9.9$ & 0.160 & 0.003 \\
\hline Heart rate, b.p.m. & $74.1 \pm 11.2$ & $75.1 \pm 12.0$ & $73.7 \pm 11.0$ & 0.099 & $74.6 \pm 11.4$ & $74.8 \pm 11.1$ & $74.1 \pm 11.2$ & 0.596 & 0.528 \\
\hline $\begin{array}{l}\text { eGFR, } \mathrm{ml} \mathrm{min}^{-1} \\
\text { per } 1.73 \mathrm{~m}^{2}\end{array}$ & $79.3 \pm 14.1$ & $79.0 \pm 14.2$ & $79.1 \pm 13.7$ & 0.053 & $51.6 \pm 6.9$ & $48.3 \pm 8.4$ & $52.4 \pm 6.1$ & $<0.001$ & $<0.001$ \\
\hline UP-positive, $n(\%)$ & $215(9.8)$ & $215(100.0)$ & $0(0.0)$ & $<0.001$ & $86(16.9)$ & $86(100.0)$ & $0(0.0)$ & $<0.001$ & $<0.001$ \\
\hline Stroke & $58(2.2)$ & $8(3.7)$ & $37(1.9)$ & 0.067 & $28(4.5)$ & $5(5.8)$ & $14(3.3)$ & 0.264 & 0.001 \\
\hline Angina pectoris & $59(2.2)$ & $5(2.3)$ & $39(2.0)$ & 0.719 & $35(5.7)$ & $8(9.3)$ & $20(4.7)$ & 0.090 & $<0.001$ \\
\hline Myocardial infarction & $12(0.4)$ & $1(0.5)$ & $11(0.6)$ & 0.867 & $10(1.6)$ & $3(3.5)$ & $7(1.7)$ & 0.264 & 0.001 \\
\hline Diabetes & $382(14.3)$ & $58(27.0)$ & 277 (13.9) & $<0.001$ & $85(13.8)$ & $22(25.6)$ & $53(12.5)$ & 0.002 & 0.728 \\
\hline Dyslipidemia & $1042(39.0)$ & 90 (41.9) & $777(39.1)$ & 0.435 & $263(42.6)$ & $41(47.7)$ & $175(41.4)$ & 0.281 & 0.103 \\
\hline Current smoking & $1088(40.7)$ & $110(51.2)$ & $813(40.9)$ & 0.004 & $212(34.3)$ & $45(52.3)$ & $138(32.6)$ & 0.001 & 0.003 \\
\hline \multicolumn{10}{|l|}{ Previous medication } \\
\hline Antihypertensive agents & $2127(79.6)$ & $165(76.7)$ & $1586(79.9)$ & 0.282 & $502(81.2)$ & $70(81.4)$ & $336(79.4)$ & 0.680 & 0.363 \\
\hline Benidipine & $1693(63.4)$ & $133(61.9)$ & $1293(65.1)$ & 0.344 & $387(62.6)$ & $60(69.8)$ & $259(61.2)$ & 0.136 & 0.731 \\
\hline Other CCB & $288(10.8)$ & $24(11.2)$ & $201(10.1)$ & 0.632 & 76 (12.3) & $3(3.5)$ & $56(13.2)$ & 0.010 & 0.278 \\
\hline ARB & $231(8.6)$ & $16(7.4)$ & $154(7.8)$ & 0.871 & $73(11.8)$ & $6(7.0)$ & $43(10.2)$ & 0.361 & 0.014 \\
\hline Antidiabetic agents & $189(7.1)$ & $30(14.0)$ & $136(6.8)$ & $<0.001$ & $47(7.6)$ & $10(11.6)$ & $35(8.3)$ & 0.318 & 0.644 \\
\hline
\end{tabular}

Abbreviations: ACE, angiotensin-converting enzyme; ARB, angiotensin receptor blocker; BB, $\beta$-blocker; BP, blood pressure; CCB, calcium-channel blocker; eGFR, estimated glomerular filtration rate; UP, urinary protein.

Data are shown as number of patients (\%) or mean \pm s.d.

${ }^{a} P$-value for UP-positive vs. UP-negative.

b $P$-value for baseline eGFR $\geqslant 60 \mathrm{ml} \mathrm{min}^{-1}$ per $1.73 \mathrm{~m}^{2}$ vs. Baseline eGFR $<60 \mathrm{ml} \mathrm{min}^{-1}$ per $1.73 \mathrm{~m}^{2}$.

benidipine-ARB treatment group of patients positive for urinary protein, and a significant decrease in eGFR was observed with all three therapies in patients negative for urinary protein; however, there was no significant difference among treatment groups. For the group of patients with a baseline eGFR $<60 \mathrm{ml} \mathrm{min}^{-1}$ per $1.73 \mathrm{~m}^{2}$, no significant decrease in eGFR was observed with any treatment therapy in patients positive for urinary protein, whereas a significant increase in eGFR was observed with all three therapies in patients negative for urinary protein.

Among the 618 patients with an eGFR $<60 \mathrm{ml} \mathrm{min}^{-1}$ per $1.73 \mathrm{~m}^{2}$, 327 patients $(52.9 \%)$ had been evaluated for urinary protein both at baseline and at the end of the treatment phase. The number (percentage) of patients positive for urinary protein in the benidipine-ARB, benidipine-BB and benidipine-TD groups changed from 23/121 (19.0\%), 11/90 (12.2\%) and 19/116 (16.4\%), respectively, at baseline to $20 / 121$ (16.5\%), $7 / 90(7.8 \%)$ and $17 / 116(14.7 \%)$, respectively, at the end of the treatment phase. No significant difference was observed among the treatment groups or between the two time points.

\section{DISCUSSION}

The results of this subanalysis of the COPE trial provide valuable data on concomitant treatment using antihypertensive drugs with a $\mathrm{Ca}$ antagonist as the basal agent for hypertensive patients with CKD. The results showed that in the CKD subgroup, there was no difference in the prevention of cardiovascular events among the benidipine-ARB, benidipine-BB and benidipine-TD groups. On the other hand, the results showed that the incidence of new-onset diabetes in hypertensive patients with CKD was significantly lower in the benidipine-ARB group than in the benidipine-TD group. The analysis of all patients in the COPE trial showed that the incidence of 

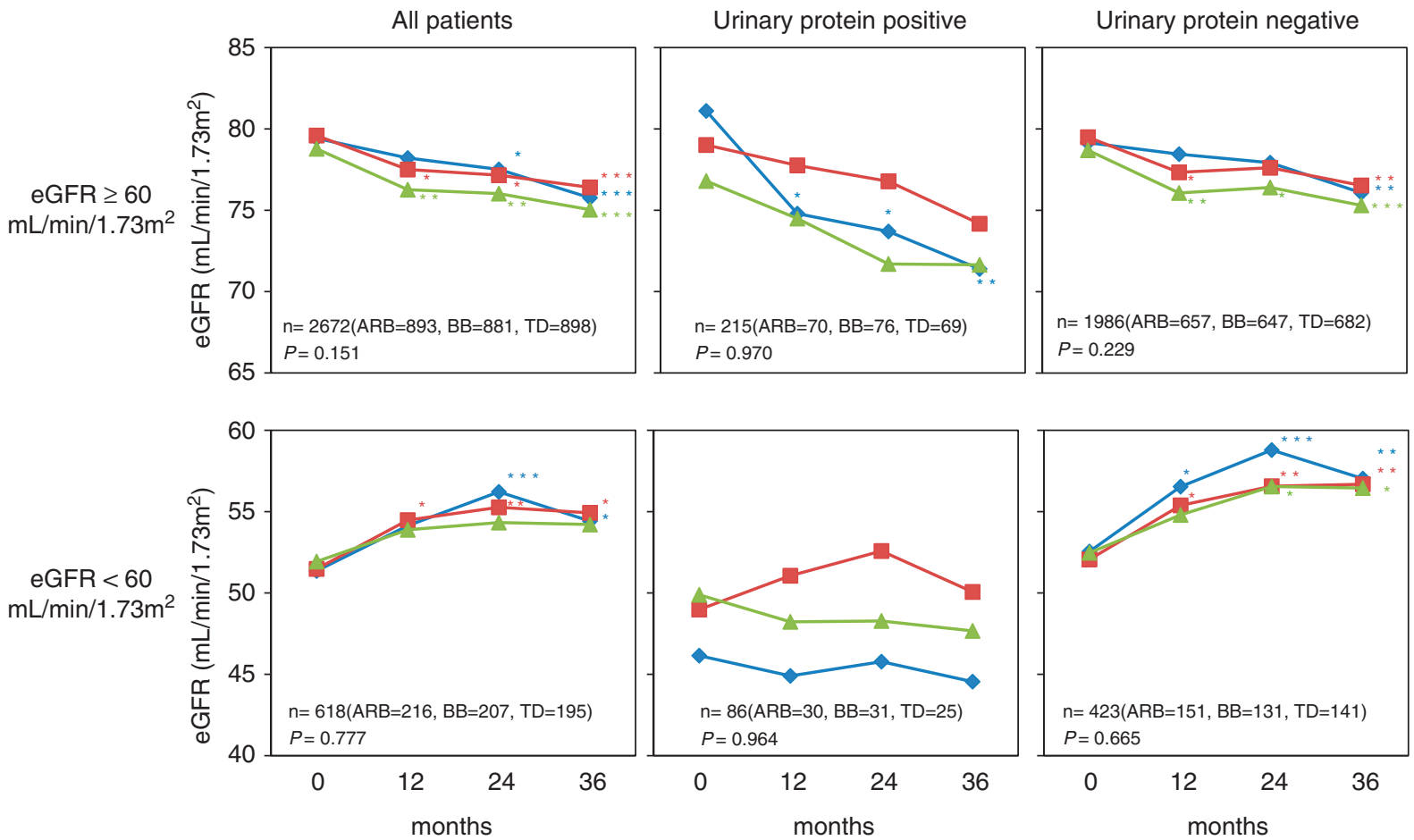

Benidipine plus ARB
Benidipine plus BB
$\triangle$ Benidipine plus TD

* : $P<0.05$ vs baseline

$*_{*}^{*}: P<0.005$ vs baseline

*** : $P<0.0005$ vs baseline

Figure 4 Effects of treatment on estimated glomerular filtration rate (eGFR). ARB, angiotensin receptor blocker; BB, $\beta$-blocker; TD, thiazide diuretic.

new-onset diabetes was significantly lower in the benidipine-ARB group than in the benidipine-BB group. ${ }^{16}$ Thus, the results of the COPE trial and the present ones are consistent with those reported by Elliott and Meyer ${ }^{19}$ who found that ARB prevented the occurrence of new-onset diabetes.

CKD treatment aims at preventing cardiovascular events and the progression of CKD to end-stage kidney disease; therefore, preventing a decrease of eGFR is important. Bakris et al. ${ }^{20}$ reported that the lower the achieved BP was, the slower the decreasing speed of GFR was, and they estimated that when the BP target of $130 / 80 \mathrm{~mm} \mathrm{Hg}$ was achieved, the speed of eGFR was approximately $1 \mathrm{ml} \mathrm{min}^{-1}$ per $1.73 \mathrm{~m}^{2}$. In the COPE trial in which a similar degree of BP control was attained, the eGFR decreased by 3 to $4 \mathrm{ml} \mathrm{min}^{-1}$ per $1.73 \mathrm{~m}^{2}$ after 3 years of treatment in all treatment groups consisting of patients with a baseline eGFR $\geqslant 60 \mathrm{ml} \mathrm{min}^{-1}$ per $1.73 \mathrm{~m}^{2}$; the decreasing speed was similar to that reported by Bakris et al. ${ }^{20}$ There was no significant difference in the change in eGFR among the three treatment groups, and a similar efficacy was observed.

The group of patients with a baseline eGFR $\geqslant 60 \mathrm{ml} \mathrm{min}^{-1}$ per $1.73 \mathrm{~m}^{2}$ was distributed into those positive and negative for urinary protein; however, even after the distribution, there was no significant difference in the change of eGFR among the three therapy groups. In the urinary protein-positive group, part of the group of patients with a baseline eGFR $\geqslant 60 \mathrm{ml} \mathrm{min}^{-1}$ per $1.73 \mathrm{~m}^{2}$, a significant decrease in eGFR was observed only in the benidipine plus ARB group. Bakris and Weir $^{21}$ showed in their review that eGFR decreased in the initial phase of treatment with renin-angiotensin system blockers. We assumed that in the urinary protein-positive group, although urinary protein does not reflect glomerular hyperfiltration alone, glomerular hyperfiltration resulted in a marked decrease of eGFR in the initial phase of treatment due to ARB.

In the subset analysis of the Japanese Trial to Assess Optimal Systolic Blood Pressure in Elderly Hypertensive Patients (JATOS), eGFR in the group of patients with a baseline eGFR $<60 \mathrm{ml} \mathrm{min}^{-1}$ per $1.73 \mathrm{~m}^{2}$ showed a small, but significant, increase from 49 to $55 \mathrm{ml} \mathrm{min}^{-1}$ per $1.73 \mathrm{~m}^{2}$, and the eGFR of all patients also increased from 59 to $61-62 \mathrm{ml} \mathrm{min}^{-1}$ per $1.73 \mathrm{~m}^{2}{ }^{22}$ In the COPE trial as well, eGFR increased in the group of patients with a baseline eGFR $<60 \mathrm{ml} \mathrm{min}^{-1}$ per $1.73 \mathrm{~m}^{2}$, regardless of concomitant drugs. The eGFR decreased in all patients who participated in the COPE trial, whereas it increased in all the patients included in the JATOS study. The baseline eGFR in the COPE trial was $74 \mathrm{ml} \mathrm{min}^{-1}$ per $1.73 \mathrm{~m}^{2}$, whereas the baseline eGFR in the JATOS study was $59 \mathrm{ml} \mathrm{min}^{-1}$ per $1.73 \mathrm{~m}^{2}$ because the latter study was conducted in elderly people. The reason for the finding that eGFR decreased in all patients in the COPE trial was probably because the proportion of patients with a baseline eGFR $<60 \mathrm{ml} \mathrm{min}^{-1}$ per $1.73 \mathrm{~m}^{2}$ was small. The reason why the eGFR was maintained or gradually increased in patients with a baseline eGFR $<60 \mathrm{ml} \mathrm{min}^{-1}$ per $1.73 \mathrm{~m}^{2}$ but gradually decreased in patients with a baseline eGFR $\geqslant 60 \mathrm{mlmin}^{-1}$ per $1.73 \mathrm{~m}^{2}$ is unknown, which should be further investigated.

The fact that eGFR increased in the group of patients with a baseline eGFR $<60 \mathrm{mlmin}^{-1}$ per $1.73 \mathrm{~m}^{2}$ in the COPE trial is a substantial advantage in terms of progression to end-stage kidney disease. Although the mechanism of increased eGFR is not clear, it may be due to benidipine, the basal agent, because eGFR increased regardless of the addition of a concomitant drug. In the JATOS study, which also found an improvement of eGFR, efonidipine, which is 
both an L-type and T-type Ca-channel antagonist, was used as the study drug; benidipine has also been reported to be a T-type Cachannel antagonist. ${ }^{12}$ The effect of benidipine on T-type Ca channels may have contributed to the improvement of eGFR observed in this study. These results are consistent with a report showing that benidipine, a T/L-type Ca antagonist, inhibited renal events more effectively than L-type Ca antagonists. ${ }^{15}$ Bardoxolon, a diabetic nephropathy drug, and pirfenidone, an antifibrinolytic drug, have also been reported to improve eGFR, and their anti-inflammatory effect and antioxidant effect are considered to be their possible mechanisms of action. ${ }^{23,24}$ It has been suggested that benidipine also inhibits aldosterone secretion, has an anti-inflammatory effect and an antioxidant effect based on the inhibition of T-type Ca channels in adrenal cortex glomerulosa cells, and such effects of benidipine may contribute to the improvement of eGFR. . $^{14,25,26}$

In patients with eGFR $<60 \mathrm{ml} \mathrm{min}^{-1}$ per $1.73 \mathrm{~m}^{2}$ and positive for urinary protein, eGFR was maintained in all three treatment groups, and there was no significant difference in the change among the three groups. It was particularly interesting that in the urinary proteinnegative group, the eGFR significantly increased in all three groups, showing no significant difference among them in the change of eGFR. The present result is consistent with that of the AASK extension study showing that lower urinary protein levels and lower achieved BP levels are associated with improvement of eGFR. ${ }^{27}$ In the COPE trial, the increase in eGFR in the urinary protein-negative group may have been due to glomerular hyperfiltration; therefore, the urinary proteinnegative group was divided into two groups depending on the urinary protein status at the end of the treatment phase (urinary proteinnegative group and urinary protein-positive group) to confirm the change in eGFR. In the group of patients whose urinary protein status changed from negative to positive, hyperfiltration may have occurred, but there was no increase in eGFR $\left(49.3 \pm 6.0 \mathrm{vs} .49 .4 \pm 12.7 \mathrm{ml} \mathrm{min}^{-1}\right.$ per $1.73 \mathrm{~m}^{2}$ at baseline and the end of treatment, respectively). In the group of patients whose urinary protein status remained negative, on the other hand, there was a remarkable increase in eGFR (52.4 \pm 5.8 vs. $58.0 \pm 12.9 \mathrm{ml} \mathrm{min}^{-1}$ per $1.73 \mathrm{~m}^{2}$, respectively); therefore, it was considered that the increase in eGFR was not due to hyperfiltration.

The ACCOMPLISH trial and the gauging albuminuria reduction with lotrel in diabetic patients with hypertension (GUARD) study, in which a renin-angiotensin system blocker was used as the basal agent, found that diuretic drugs decreased the eGFR. ${ }^{28,29}$ In the ACCOMPLISH trial, eGFR in the group prescribed the concomitant use of a diuretic drug decreased in all patients $\left(-4.22 \mathrm{ml} \mathrm{min}^{-1}\right.$ per $\left.1.73 \mathrm{~m}^{2}\right)$ and the CKD group $\left(-2.3 \mathrm{ml} \mathrm{min}^{-1}\right.$ per $\left.1.73 \mathrm{~m}^{2}\right)$ during the 2.9-year follow-up period. In the GUARD study, eGFR decreased by $13.64 \mathrm{ml} \mathrm{min}^{-1}$ during the 52 -week follow-up period. In the COPE trial in which the T/L-type Ca antagonist benidipine was used as the basal agent, even in the group prescribed the concomitant use of a diuretic drug, an increase of eGFR was observed in the group of patients with a baseline eGFR $<60 \mathrm{ml} \mathrm{min}^{-1}$ per $1.73 \mathrm{~m}^{2}$ and without proteinuria. In CKD patients with normoalbuminuria or microalbuminuria, no correlation was found between reduction of albuminuria and the maintenance of eGFR, ${ }^{30}$ and it was not clear whether a certain class of drugs could be effective. The results of the COPE trial suggested that strict antihypertensive treatment with a T/Ltype $\mathrm{Ca}$ antagonist as the basal agent was effective in CKD patients with a normal urinary protein status.

As for urinary protein, a decreasing trend was observed in all treatment groups in the COPE trial, but no significant difference was observed among treatment groups or between two time points. It has been reported that benidipine dilates efferent arterioles and inhibits proteinuria by inhibiting T-type Ca channels. ${ }^{12-14}$ The fact that $>60 \%$ of the patients included in the COPE trial already used benidipine before enrollment may have made it difficult to further inhibit proteinuria by additional treatment with a concomitant drug. The fact that urinary protein was measured in only about half of the patients by the end of the treatment phase because measurement of urinary protein was not essential in this study may have influenced the results as well.

The hazard ratio for cardiovascular hard composite end points in the non-CKD subgroup was significantly lower in the benidipine-TD group than in the benidipine-BB group, which was consistent with the results in all patients of the COPE trial. ${ }^{16}$ On the other hand, the hazard ratio for fatal and non-fatal strokes was significantly lower in the benidipine-ARB group than in the benidipine-BB group, which differed from the finding that the hazard ratio was significantly lower in the benidipine-TD group in all patients. In the group of patients with a baseline eGFR $\geqslant 60 \mathrm{ml} \mathrm{min}^{-1}$ per $1.73 \mathrm{~m}^{2}$, there were 471 patients with unknown urinary protein status; these patients were excluded because it was not confirmed whether they had CKD or not. Among the excluded patients, there were four patients in the benidipine-ARB group, four patients in the benidipine-BB group and one patient in the benidipine-TD group who had developed fatal or non-fatal stroke. The number of patients excluded because of events was larger in the benidipine-ARB and benidipine-BB groups than in the benidipine-TD group, which was considered to be the reason for the difference in the results between the patients.

\section{Study limitations}

First, we adopted the PROBE design, and so non-blinded treatment allocation could have influenced the attitude of patients and investigators toward compliance with the study medications or staying in the study. Second, because the sample size of this subanalysis was relatively small, the optimal combination therapy for CKD patients should be investigated in a future trial. Third, the facts that prevention of newonset diabetes in CKD patients was inferior in the TD diuretic group and that cardiovascular hard end points and prevention of stroke in non-CKD patients were inferior in the $\mathrm{BB}$ group should be confirmed in future studies. Finally, measurement of urinary protein was not essential for the evaluation of renal function in this study; therefore, only about half of the patients had this parameter assessed by the end of the treatment phase. The fact that eGFR showed a small, but significant, increase in the group of patients with an eGFR $<60 \mathrm{ml} \mathrm{min}^{-1}$ per $1.73 \mathrm{~m}^{2}$ is important; therefore, it should be confirmed by inulin clearance, the gold standard of GFR evaluation.

In conclusion, calcium-channel blocker combined with an ARB, a $\mathrm{BB}$ or a TD diuretic, was similarly effective regarding prevention of cardiovascular events and the achievement of target BP in hypertensive patients with or without CKD who did not reach the target BP with $4 \mathrm{mg}$ per day of benidipine alone. Concerning the effect on eGFR, there was no significant difference among the three treatment groups either; however, an improvement of eGFR was observed in the group of patients with an eGFR $<60 \mathrm{ml} \mathrm{min}^{-1}$ per $1.73 \mathrm{~m}^{2}$, and there was a marked increase of eGFR especially in the urinary proteinnegative group. In $\mathrm{CKD}$ patients with normal proteinuria, antihypertensive treatment with a T/L-type $\mathrm{Ca}$ antagonist as the basal agent may be effective for maintenance of eGFR.

\section{CONFLICT OF INTEREST}

All the authors report receiving lecture fees from various pharmaceutical companies in Japan, including Kyowa Hakko Kirin. 


\section{ACKNOWLEDGEMENTS}

We thank the collaborators and members of the COPE trial group. The present trial was conducted as a collaborative research between Yamaguchi University and the sponsor (Kyowa Hakko Kirin). This study was endorsed by the Japanese Society of Hypertension.

1 Ogihara T, Saruta T, Rakugi H, Fujimoto A, Ueshima K, Yasuno S, Oba K, Takeda K, Higaki J, Nakao KCASE-J trial Group. Relationship between the achieved blood pressure and the incidence of cardiovascular events in Japanese hypertensive patients with complications: a sub-analysis of the CASE-J trial. Hypertens Res 2009; 32 248-254.

2 Sleight P, Redon J, Verdecchia P, Mancia G, Gao P, Fagard R, Schumacher H, Weber M, Böhm M, Williams B, Pogue J, Koon T, Yusuf SONTARGET investigators. Prognostic value of blood pressure in patients with high vascular risk in the Ongoing Telmisartan Alone and in combination with Ramipril Global Endpoint Trial study. J Hypertens 2009; 27: 1360-1369.

3 Strippoli GF, Craig M, Deeks JJ, Schena FP, Craig JC. Effects of angiotensin converting enzyme inhibitors and angiotensin II receptor antagonists on mortality and renal outcomes in diabetic nephropathy: systematic review. $B M$ 2004; 329: 828

4 Hou FF, Zhang X, Zhang GH, Xie D, Chen PY, Zhang WR, Jiang JP, Liang M, Wang GB, Liu ZR, Geng RW. Efficacy and safety of benazepril for advanced chronic renal insufficiency. N Engl J Med 2006: 354: 131-140.

5 Estacio RO, Jeffers BW, Gifford N, Schrier RW. Effect of blood pressure control on diabetic microvascular complications in patients with hypertension and type 2 diabetes. Diabetes Care 2000; 23 (Suppl 2), B54-B64.

6 Rahman M, Pressel S, Davis BR, Nwachuku C, Wright JT Jr, Whelton PK, Barzilay J, Batuman V, Eckfeldt JH, Farber M, Henriquez M, Kopyt N, Louis GT, Saklayen M, Stanford C, Walworth C, Ward H, Wiegmann T. Renal outcomes in high-risk hypertensive patients treated with an angiotensin-converting enzyme inhibitor or calcium channel blocker vs a diuretic: a report from the Antihypertensive and LipidLowering Treatment to Prevent Heart Attack Trial (ALLHAT). Arch Intern Med 2005, 165: 936-946.

7 Mancia G, De Backer G, Dominiczak A, Cifkova R, Fagard R, Germano G, Grassi G, Heagerty AM, Kjeldsen SE, Laurent S, Narkiewicz K, Ruilope L, Rynkiewicz A, Schmieder RE, Boudier HA, Zanchetti A, Vahanian A, Camm J, De Caterina R, Dean V, Dickstein K, Filippatos G, Funck-Brentano C, Hellemans I, Kristensen SD, McGregor K, Sechtem U, Silber S, Tendera M, Widimsky P, Zamorano JL, Erdine S, Kiowski W, Agabiti-Rosei E, Ambrosioni E, Lindholm LH, Viigimaa M, Adamopoulos S, Bertomeu V, Clement D, Farsang C, Gaita D, Lip G, Mallion JM, Manolis AJ, Nilsson PM, O'Brien E, Ponikowski P, Redon J, Ruschitzka F, Tamargo J, van Zwieten P, Waeber B, Williams B, Management of Arterial Hypertension of the European Society of Hypertension; European Society of Cardiology. 2007 Guidelines for the Management of Arterial Hypertension: The task force for the management of arterial hypertension of the European Society of Hypertension (ESH) and of the European Society of Cardiology (ESC). $J$ Hypertens 2007; 25: 1105-1187.

8 Ogihara T, Kikuchi K, Matsuoka H, Fujita T, Higaki J, Horiuchi M, Imai Y, Imaizumi T, Ito $\mathrm{S}$, I wao $\mathrm{H}$, Kario $\mathrm{K}$, Kawano $\mathrm{Y}$, Kim-Mitsuyama $\mathrm{S}$, Kimura $\mathrm{G}$, Matsubara $\mathrm{H}$ Matsuura H, Naruse M, Saito I, Shimada K, Shimamoto K, Suzuki H, Takishita S, Tanahashi N, Tsuchihashi T, Uchiyama M, Ueda S, Ueshima H, Umemura S, Ishimitsu T, Rakugi $\mathrm{H}$, Japanese Society of Hypertension Committee. The Japanese Society of Hypertension Guidelines for the Management of Hypertension (JSH 2009). Hypertens Res 200932: 3-107.

9 Sarafidis PA, Bakris GL. Resistant hypertension: an overview of evaluation and treatment. J Am Coll Cardiol 2008; 52: 1749-1757.

10 Jamerson K, Weber MA, Bakris GL, Dahlöf B, Pitt B, Shi V, Hester A, Gupte J, Gatlin M, Velazquez EJ, ACCOMPLISH Trial Investigators. Benazepril plus amlodipine or hydrochlorothiazide for hypertension in high-risk patients. N Engl J Med 2008; 359 2417-2428.

11 Yao K, Nagashima K, Miki H. Pharmacological, pharmacokinetic, and clinical properties of benidipine hydrochloride, a novel, long-acting calcium channel blocker. J Pharmacol Sci 2006; 100: 243-261.

12 Hayashi K, Wakino S, Sugano N, Ozawa Y, Homma K, Saruta T. Ca2 + channel subtypes and pharmacology in the kidney. Circ Res 2007; 100: 342-353.
13 Abe M, Okada K, Maruyama N, Matsumoto S, Maruyama T, Fujita T, Matsumoto K, Soma M. Benidipine reduces albuminuria and plasma aldosterone in mild-to-moderat stage chronic kidney disease with albuminuria. Hypertens Res 2011; 34: 268-273.

14 Nakamura T, Sato E, Fujiwara N, Kawagoe Y, Ueda Y, Sugaya T, Yamagishi S, Yamada S, Koide H. Comparative effects of benidipine and amlodipine on proteinuria, urinary $8-\mathrm{OHdG}$, urinary L-FABP, and inflammatory and atherosclerosis markers in early-stage chronic kidney disease. Am J Med Sci 2010; 339: 157-163.

15 Omae K, Ogawa T, Nitta K. Influence of T-calcium channel blocker treatment on deterioration of renal function in chronic kidney disease. Heart Vessels 2009; 24 301-307.

16 Matsuzaki M, Ogihara T, Umemoto S, Rakugi H, Matsuoka H, Shimada K, Abe K, Suzuki N, Eto T, Higaki J, Ito S, Kamiya A, Kikuchi K, Suzuki H, Tei C, Ohashi Y, Saruta T, Combination Therapy of Hypertension to Prevent Cardiovascular Events Trial Group. Prevention of cardiovascular events with calcium channel blocker-based combination therapies in patients with hypertension: a randomized controlled trial. J Hypertens 2011; 29: 1649-1659.

17 Ogihara T, Matsuzaki M, Umemoto S, Rakugi H, Matsuoka H, Shimada K, Higaki J, Ito S, Kamiya A, Suzuki H, Ohashi Y, Shimamoto K, Saruta T, Combination Therapy of Hypertension to Prevent Cardiovascular Events Trial Group. Combination therapy for hypertension in the elderly: a sub-analysis of the Combination Therapy of Hypertension to Prevent Cardiovascular Events (COPE) trial. Hypertens Res 2012; 35: 441-448.

18 Matsuo S, Imai E, Horio M, Yasuda Y, Tomita K, Nitta K, Yamagata K, Tomino Y Yokoyama $\mathrm{H}$, Hishida A, Collaborators developing the Japanese equation for estimated GFR. Revised equations for estimated GFR from serum creatinine in Japan. Am J Kidney Dis 2009; 53: 982-992.

19 Elliott WJ, Meyer PM. Incident diabetes in clinical trials of antihypertensive drugs: a network meta-analysis. Lancet 2007; 369: 201-207.

20 Bakris GL, Williams M, Dworkin L, Elliott WJ, Epstein M, Toto R, Tuttle K, Douglas J, Hsueh W, Sowers J. Preserving renal function in adults with hypertension and diabetes: a consensus approach. National Kidney Foundation Hypertension and Diabetes Executive Committees Working Group. Am J Kidney Dis 2000; 36: 646-661.

21 Bakris GL, Weir MR. Angiotensin-converting enzyme inhibitor-associated elevations in serum creatinine: is this a cause for concern? Arch Intern Med 2000; 160: 685-693.

22 Hayashi K, Saruta T, Goto Y, Ishii M, JATOS Study Group. Impact of renal function on cardiovascular events in elderly hypertensive patients treated with efonidipine. Hypertens Res 2010; 33: 1211-1220.

23 Pergola PE, Raskin P, Toto RD, Meyer CJ, Huff JW, Grossman EB, Krauth M, Ruiz S, Audhya P, Christ-Schmidt H, Wittes J, Warnock DG, BEAM Study Investigators. Bardoxolone methyl and kidney function in CKD with type 2 diabetes. N Engl J Med 2011; 365: 327-336

24 Sharma K, Ix JH, Mathew AV, Cho M, Pflueger A, Dunn SR, Francos B, Sharma S, Falkner B, McGowan TA, Donohue M, Ramachandrarao S, Xu R, Fervenza FC, Kopp JB. Pirfenidone for diabetic nephropathy. J Am Soc Nephrol 2011; 22: 1144-1151.

25 Akizuki O, Inayoshi A, Kitayama T, Yao K, Shirakura S, Sasaki K, Kusaka H, Matsubara M. Blockade of T-type voltage-dependent $\mathrm{Ca} 2+$ channels by benidipine, a dihydropyridine calcium channel blocker, inhibits aldosterone production in human adrenocortical cell line NCl-H295R. Eur J Pharmacol 2008; 584: 424-434.

26 Yamamoto E, Kataoka K, Dong YF, Nakamura T, Fukuda M, Nako H, Ogawa H, KimMitsuyama S. Benidipine, a dihydropyridine L-type/T-type calcium channel blocker, affords additive benefits for prevention of cardiorenal injury in hypertensive rats. J Hypertens 2010; 28: 1321-1329.

27 Hu B, Gadegbeku C, Lipkowitz MS, Rostand S, Lewis J, Wright JT, Appel LJ, Greene T, Gassman J, Astor BC, African-American Study of Kidney Disease and Hypertension Group. Kidney function can improve in patients with hypertensive CKD. J Am Soc Nephrol 2012; 23: 706-713.

28 Bakris GL, Sarafidis PA, Weir MR, Dahlöf B, Pitt B, Jamerson K, Velazquez EJ, StaikosByrne L, Kelly RY, Shi V, Chiang YT, Weber MA, ACCOMPLISH Trial investigators. Rena outcomes with different fixed-dose combination therapies in patients with hypertension at high risk for cardiovascular events (ACCOMPLISH): a prespecified secondary analysis of a randomised controlled trial. Lancet 2010; 375: 1173-1181.

29 Bakris GL, Toto RD, McCullough PA, Rocha R, Purkayastha D, Davis P, GUARD (Gauging Albuminuria Reduction With Lotrel in Diabetic Patients With Hypertension) Study Investigators. Effects of different ACE inhibitor combinations on albuminuria: results of the GUARD study. Kidney Int 2008; 73: 1303-1309.

30 Jerums G, Panagiotopoulos S, Premaratne E, Power DA, Maclsaac RJ. Lowering of proteinuria in response to antihypertensive therapy predicts improved renal function in late but not in early diabetic nephropathy: a pooled analysis. Am J Nephrol 2008; 28: 614-627

Supplementary Information accompanies the paper on Hypertension Research website (http://www.nature.com/hr)

\section{APPENDIX}

Principal Study Coordinator-T Ogihara.

Study Adviser-T Saruta.

Steering Committee-M Matsuzaki (Chairperson), T Eto, T Fujita,

J Higaki, S Ito, A Kamiya, K Kikuchi, H Matsuoka and H Suzuki, C Tei. Protocol Committee-H Matsuoka (Chairperson), H Kumagai, Y Ohashi, H Rakugi, K Shimamoto, S Takishita and S Umemoto.
Endpoint Classification Committee-K Shimada (Chairperson), K Hayashi, K Kario, M Kawana, K Kitagawa, H Makino, M Matsumoto and J Yoshikawa.

Independent Data Monitoring Committee-K Abe (Chairperson), H Matsuura, Y Ohashi, K Otsuka and K Tanabe.

Safety Committee-N Suzuki (Chairperson), S Nogawa, K Utsunomiya, T Yoshikawa and $\mathrm{W}$ Yumura. 
Study Statistician-Y Ohashi.

Coordinating Center-S Umemoto (EBM Office, Center for Clinical Research, Yamaguchi University Hospital).

Investigators:

HOKKAIDO DISTRICT-K Kikuchi, N Hasebe, M Bunya, W Fujii, N Funayama, M Gima, K Hashizume, Y Hirayama, H Matsuhashi, $\mathrm{H}$ Morimoto, $\mathrm{T}$ Myojo, K Ohori, $\mathrm{H}$ Omiya, $\mathrm{T}$ Ota, A Sato, T Shiokoshi, H Tanaka, K Yamazaki, H Yoshie, K Shimamoto, M Abiru, M Adachi, Y Fujise, K Hanawa, K Ishii, Y Kadono, T Kaku, S Kaneta, M Kato, N Kato, H Kobayashi, T Komakine, T Matsumoto, T Mita, N Miura, H Mukai, K Nagao, H Nakagawa, M Nakagawa, $\mathrm{N}$ Nakajima, $\mathrm{T}$ Nishimiya, Y Nishino, A Nunokawa, J Ohata, H Ooiwa, R Sato, S Satoh, S Shibata, M Takada, Y Takagawa, Y Takagi, S Takeichi, S Tanaka, N Togashi, N Ura, C Wakabayashi, D Yoshida, H Yoshida, K Yoshida, A Kitabatake, H Tsutsui, M Akutsu, S Fujii, T Furumoto, S Kakinoki, $\mathrm{H}$ Kawasaki, $\mathrm{T}$ Kimura, M Makiguchi, H Matsuo, H Okamoto, Y Oyama, J Shimokawa and $\mathrm{N}$ Tsuzuki.

TOHOKU DISTRICT—S Ito, Y Imai, R Domon, H Ebina, S Egawa, T Haruyama, H Hashimoto, T Hayakawa, H Inomata, Y Katahira, T Katakura, R Kikuchi, H Kimura, S Kyogoku, Y Kyogoku, K Matsuo, H Nakazawa, H Odakura, F Okuguchi, E Ohtomo, H Ouchi, M Seino, $\mathrm{M}$ Tadokoro, $\mathrm{Y}$ Tanno, $\mathrm{N}$ Uchida, $\mathrm{T}$ Yamanaka, K Yunomura, K Okumura, T Hatayama, Y Kanehira, H Kaneko, M Kimura, N Maeda, A Mikuniya, H Narita, M Ono, T Osanai and M Sato.

TOKYO DISTRICT - H Yoshino, S Momomura, M Ono, M Inoue, T Iwase, K Miyazaki, M Taki, T Aizawa, Y Hasunuma, H Makino, H Okabayashi, S Hosoda, T Sumiyoshi, M Abe, Y Kira, M Nagayama, K Sakai, O Yoshikawa, M Ide, N Kimura, S Matsuzaka, Y Miyajima, K Sawai, T Sumi, R Takada, M Toma, Y Yamada, K Yoda, T Yokokawa, S Yokoyama, K Kanmatsuse, T Kushiro, T Anazawa, T Ebuchi, H Fujita, N Katsumata, K Masubuchi, T Migita, T Osada, Y Otsuka, F Saito, S Shimoda, K Sugino, A Takahashi, S Tani, K Yumi, H Daida, T Arino, T Iesaki, Y Inomata, H Nakahara, H Shiraishi, H Sudo, T Degawa, T Araki, H Itaya, H Komatsu, H Kuwana, T Mikawa, H Nomoto, N Ogawa, H Sato, H Takase, H Toyoda, M Yamamoto, K Obayashi, I Akabane, H Hamamoto, $\mathrm{R}$ Kanbara, $\mathrm{H}$ Kato, H Kimura, N Mori, K Yamada, M Yamamuro, M Isobe, H Emoto, $\mathrm{O}$ Inaba, $\mathrm{T}$ Inazawa, $\mathrm{H}$ Inomata, $\mathrm{K}$ Isobe, $\mathrm{Y}$ Ito, $\mathrm{M}$ Komura, H Kosuge, Y Maejima, N Miwa, T Nishimori, K Otomo, K Sakurai, M Sawada, M Seya, M Shimizu, T Takagi, M Tamura, K Tanaka, D Tezuka, T Tokunaga, A Yagishita, A Yamashina, T Hara, S Hayashi, Y Hirayama, Y Hirooka, M Iitaka, T Ishiyama, F Kijima, H Kobayashi, Y Kobayashi, K Kondo, T Kuwabara, M Mugishima, Y Nakayama, Y Nishizato, Y Osamura, Y Sakomura, S Saneshige, N Shindo, $\mathrm{N}$ Takao, Y Takata, $\mathrm{H}$ Tomiyama, S Ishimaru, Y Obitsu, H Shigematsu, T Baba, H Fukushima, T Hirayama, K Magari, S Makimura, T Nagae, K Osada, T Osada, T Shimizu, H Suesada, K Tamura, T Yamazaki, A Hirai, T Fukasawa, H Ono, M Yamakado, T Shiba, S Otomi, A Uehata, K Takazawa, A Aizawa, T Iketani, M Kino, H Kobayashi, T Morishima, N Sakamoto, T Sakamoto, $\mathrm{H}$ Yamakawa, $\mathrm{H}$ Kasanuki, $\mathrm{R}$ Nagai, $\mathrm{T}$ Kadowaki, J Tanaka, T Yamazaki, M Takagi, S Ui, S Baba, K Fujita, T Hasegawa, K Tajima, M Tanaka, N Yamato, I Kuwajima, K Harada, H Miyata, S Mizuno, S Ueda, K Sugi, H Ando, K Mishima, M Moroi, S Nishizawa, S Suzuki, J Yamazaki, R Nakanishi, H Nakano, K Tokuyasu, T Aoyagi, M Fujioka, N Kobayakawa, K Nakajima, A Hirayama, K Tsukamoto, Y Araki, H Hara, K Hara and T Saruya.

KANAGAWA DISTRICT-S Umemura, $\mathrm{M}$ Arima, $\mathrm{T}$ Endo, K Furumi, Y Hatori, Y Ikeda, Y Ikeya, T Kaneda, T Kawada,
T Kawano, $\mathrm{T}$ Kawashima, $\mathrm{M}$ Kihara, M Kikuta, A Kitamura, H Kobayashi, S Kobayashi, T Kuji, S Masuda, Y Minamimoto, K Minamisawa, T Mitsuhashi, N Miyazaki, Z Nagashima, T Nakatogawa, R Nakayama, N Nyui, M Ogawa, T Onishi, K Saka, T Sano, A Sato, K Shiba, F Shionoiri, H Sugiyama, H Suzuki, I Takasaki, K Tamura, Y Tokita, M Umemura, S Yamaguchi and G Yasuda.

CHIBA-SAITAMA DISTRICT-S Nakamura, K Takayanagi, T Hayashi, M Ichihara, S Kobayashi, Y Sakai, T Uchida, I Yaguchi, I Komuro, S Aoki, Y Hashimoto, C Ibuki, Y Isobe, R Kumasaka, M Matsuda, K Mizuno, D Murakami, S Nakamura, M Nakatani, T Ohba, T Ohara, T Okumura, A Saito, T Sakurai, S Sato, W Sato, K Seimiya, Y Seino, K Shimizu, M Takano, K Tokuyama, D Uchida and $\mathrm{K}$ Yodogawa.

KITAKANTO-KOSHINETSU DISTRICT_S Oshima, M Kurabayashi, N Baba, Y Furushima, T Goto, T Hosoi, T Iijima, K Ito, Y Iwata, H Kubo, M Matsumoto, M Miyazaki, F Naganuma, K Nakada, M Tokushima, K Tsunoda, S Wakamatsu, Y Yagihara, Y Aizawa, M Aizawa, M Aizawa, N Hayashi, T Hori, H Kobayashi, M Kodama, K Maeda, K Miura, K Okada, Y Okura, Y Sasagawa, S Takizawa, $\mathrm{M}$ Tamura and T Yamamoto.

TOKAI DISTRICT-T Murohara, Y Awaji, H Funahashi, D Hayashi, M Iida, D Ishihara, S Ishikawa, S Kamide, M Kanashiro, N Kurebayashi, S Kyo, H Matsui, K Matsuo, M Morishima, H Noda, T Noda, N Okumura, T Ota, S Shimizu, F Somura, Y Takada, Y Takeichi, H Takezawa, T Uchikawa, D Yoshikawa, G Kimura, Y Ando, M Hoshiai, N Okuda, S Suzuki, K Takada, N Takada, K Yamada, H Hishida, T Furuta, H Hayashi, K Ito, K Kato, M Nomura, T Ota, M Ohtsuki, T Tabata, S Taga, R Tateishi, T Ito, M Fukuda, T Iwa, Y Wakida, T Yonemoto, M Watarai, M Ito, H Kawai, Y Murata, S Nomoto, K Takemoto, N Tsuboi, Y Yoshida, $\mathrm{N}$ Inoue, $\mathrm{M}$ Ishikawa, $\mathrm{M}$ Matsumoto, $\mathrm{T}$ Muramatsu, $\mathrm{R}$ Yoshida, M Ono, Y Hanaki, H Sano, Y Shibata, K Sakai, M Ajioka, H Asano, R Okamoto, H Osanai, Y Uemura, K Yokoi, T Tanaka, H Kamiya, K Miki, M Niwa, H Fujiwara, S Minatoguchi, T Arai, S Kato, H Kobayashi, T Minagawa, N Mori, K Nakahara, Y Shimizu, M Tadokoro, N Takahashi, T Shigemasa, I Kobayashi, T Nakano, M Ito, A Fukui, Y Higashi, T Ito, U Kano, K Makino, K Nakai, M Nakajima, T Nakajima, K Sekoguchi, T Tanaka and T Tanigawa.

HOKURIKU DISTRICT - N Takekoshi, H Enyama, T Hirakawa, J Ito, T Ito, H Kakuda, T Kigoshi, K Kondo, K Masuya, M Matoba, A Nakagawa, T Nakahashi, H Nakato, H Okada, M Okuro, Y Takeuchi, H Tsugawa, T Urata, M Yasuhara, M Shimizu, H Ino, T Araki, N Fujino, T Haraki, K Hayashi, S Hifumi, T Konno, M Minamoto, S Miyamoto, M Mori, C Nakanishi, Y Sakamoto, K Sakata, S Takeda, K Ueda, K Uchiyama, S Takata, S Kaneko, I Aburadani, I Inoki, K Kitano, D Kobayashi, K Kontani, M Maekawa, M Maruyama, K Matsunuma, Y Nagai, Y Nagata, M Okajima, K Otowa, Y Sekiguchi, K Shinmura, S Usui, H Yokoyama and M Yonejima.

KINKI DISTRICT-K Nakao, N Hiraiwa, T Ko, I Masuda, T Nagae, K Nishino, M Sakamoto, T Kita, Y Nakagawa, T Kimura, T Doi, H Horiuchi, M Kinoshita, M Mizuno, M Ohnishi, K Shigemoto, A Wada, T Yamada, $\mathrm{H}$ Yoshida, M Nakagawa, H Matsubara, K Furukawa, T Hatta, A Inoue, H Katsume, A Masui, S Matsumoto, T Seki, K Takeda, Y Taniguchi, H Tsuji, Y Saito, Y Fukuoka, M Iwano, T Katsuyama, A Nakatani, Y Sakaguchi, T Konishi, T Izumi, I Toda, A Kamimoto, Y Nagai, E Matsuwaka, R Matsuwaka, K Takei, R Ueda, N Wakaki, T Iwasaka, H Hamada, S Hamada, H Koga, H Koito, K Kono, H Kurihara, J Maeda, S Morimoto, Y Takayama, T Aoyama, M Imai, T Ii, S Kashii, M Maenaka, H Ohashi, T Suyama, M Matsuda, Y Aoyagi, K Kunisada, $\mathrm{T}$ Mori, $\mathrm{T}$ Mori, J Uemura, $\mathrm{Y}$ Yokoi, $\mathrm{N}$ Morioka, $\mathrm{T}$ Ozaki, 
K Kanamasa, K Ishikawa, S Miyazaki, S Arima, T Kai, A Kurooka, I Shimada, M Takewa, M Taniguchi, R Hattori, K Haba, R Yokota, $\mathrm{H}$ Matsui, $\mathrm{E}$ Tone, $\mathrm{H}$ Yamahira, $\mathrm{T}$ Kawarabayashi, $\mathrm{H}$ Inaba, Y Sakaguchi, Y Yamamoto, H Ito, M Date, M Dodo, K Fujii, M Imai, K Inoue, Y Kanoh, N Komura, S Senpuku, M Takeda, H Tateyama, K Yasui, R Yoneda, H Morita, M Kawanami, A Tahara, T Sado, T Takamura, M Taniwa, Y Kitaura, M Fukuda, H Hanada, K Nakamura, K Sawada, M Yamaguchi, K Kodama, T Higo, A Hirata, M Kanzaki, S Komatsu, K Matsuo, T Murakawa, H Nakanishi, $\mathrm{T}$ Nemoto, M Nishio, $\mathrm{N}$ Ogasawara, Y Okuyama, Y Ueda, M Imanishi, Y Kitamura, T Sakakibara, H Yoshida, H Yoshimi, T Ogihara, H Rakugi, M Akiyama, Y Ikuno, N Imai, Y Imamura, T Inoyama, K Kamide, K Katahira, S Katsuya, T Katsuya, Y Kurokawa, O Matsuki, M Matsuo, T Nakamura, E Ogura, M Ohishi, R Sasaki, K Sugimoto, J Tachi, H Tanaka, H Tanaka, T Tsunetoshi, M Yoshino, M Hori, N Awata, T Fukukawa, Y Iimori, S Iwamoto, K Sawami, M Okamura, Y Kanayama, F Nagano, H Nakayama, H Suzuki, T Amano, K Tachibana, Y Arita, M Kirino, K Sakuyama, M Shukawa, Y Nishida, T Sakamoto, S Yanagi, K Hirota, T Majima, T Ota, T Tanaka, R Nohara, T Funauchi, O Isogai, S Takashima, H Koike, M Nishimoto, Y Kawase, O Tojo, Y Chimori, H Harada, H Takeoka, S Kishi, M Yokoyama, K Hirata, J Ejiri, R Emoto, Y Furuta, K Hattori, R Kuroda, N Maehashi, H Monnaka, Y Ohashi, T Okada, H Suzuki, M Takeuchi, M Ohyanagi, M Masai, T Masuyama, M Kawabata, T Kajiya, N Daito, T Fujisawa, S Fujita, M Hasegawa, M Hirakoba, $\mathrm{T}$ Hirano, $\mathrm{Y}$ Ikeda, $\mathrm{N}$ Imai, $\mathrm{K}$ Marumoto, S Masuda, $\mathrm{T}$ Miki, M Mitsunaga, H Mitsuoka, Y Miyachi, N Mukohara, T Nagao, K Nakada, K Nishian, S Nishioka, T Ogura, Y Onishi, K Sakaguchi, I Sano, W Sano, M Shigenobu, A Tabuchi, J Takashima, Y Taniguchi, H Uchida, T Ueda and N Urabe.

CHUGOKU DISTRICT-H Makino, S Harada, S Hirakawa, H Hirata, J Ishii, K Koten, Y Nagake, T Nakajima, Y Nakamura, T Terami, K Mitsudo, M Fujii, K Fujita, E Iwano, K Kadota, Y Nishihara, Y Takaya, H Yamamoto, T Yamamoto, C Shigemasa, I Hisatome, T Kato, H Miyakoda, M Sakamoto, M Shimoyama, T Shimada, K Tanabe, Y Goto, Y Hanada, K Kawakami, J Kitamura, K Kitamura, H Nakata, N Oyake, H Sugiura, H Tsukihashi, M Matsuzaki, S Umemoto, S Aoyagi, H Aoyama, T Fujino, S Fukuta,
$\mathrm{N}$ Hiroyama, $\mathrm{Y}$ Ikeda, $\mathrm{Y}$ Inamoto, $\mathrm{R}$ Kametani, A Kamiya, Y Kanamaru, S Kotoku, A Matsushima, J Morita, Y Murano, M Nakatsuka, S Nishimura, Y Nisnimura, T Okamura, F Okuda, U Onaka, M Ozaki, A Shimizu, C Takata, M Tamitani, T Watada, $\mathrm{T}$ Watada, K Yamamoto, M Yamauchi, T Yorozu, H Yoshikane and F Yoshino.

SHIKOKU DISTRICT-J Higaki, J Doiuchi, T Fukuoka, $\mathrm{H}$ Hashimoto, $\mathrm{M}$ Igase, $\mathrm{H}$ Kadota, $\mathrm{H}$ Kaneko, $\mathrm{S}$ Komatsu, Y Matsubara, K Miyoshi, K Murakami, S Murao, T Niiya, T Ochi, A Satoh, T Seki, H Takahashi, T Yamashita, T Yoshino, M Kohno, N Fujita, T Fukui, T Hamamoto, K Hasegawa, H Hitomi, K Ihara, H Kiyomoto, H Masugata, I Matsumoto, N Takahashi, K Yoshikawa, Y Doi, M Arisawa, T Egawa, M Fukuda, Y Kawada, H Kusunose, T Maeda, N Minami, M Nishinaga, T Noguchi, K Okabayashi, K Sato, T Satomi, J Takada, S Tamura, T Usui, M Yamada, M Irahara, H Azuma, M Fujimura, H Fujino, M Fujino, E Harada, S Harada, Y Hiasa, S Hosokawa, K Kawahara, K Koshiba, M Murakami, Y Nakaya, H Nii, S Nozaki, A Ota, T Ozaki, K Sone, Y Tsutsui and $S$ Ueta.

KYUSHU DISTRICT-M Nobuyoshi, Y Fujishima, K Hisano, $\mathrm{H}$ Ikezono, $\mathrm{R}$ Imawatari, $\mathrm{Y}$ Izumi, $\mathrm{H}$ Kanai, $\mathrm{T}$ Nakamura, T Nakamura, T Noda, E Ono, S Tanaka, T Tsuiki, $\mathrm{T}$ Yanai, T Sasaguri, S Akimitsu, K Dohmen, K Fujisawa, K Fukuyo, S Harashima, T Hayashi, M Hirata, Y Hirata, N Ikeda, H Ikematsu, W Ikematsu, W Kajiyama, Y Kawakami, I Kawasaki, H Kondo, H Kusuhara, N Maeda, H Miyahara, A Motomura, K Nakamura, T Noguchi, T Okinaga, M Sato, I Shimada, H Shin, K Soejima, K Sugi, T Taniguchi, T Uwatoku, S Yamaga, K Yamaji, J Yanagi, H Yano, K Saku, M Enomoto, T Hiratsuka, K Imoto, R Kamei, H Kanaya, M Kohara, M Kusuda, H Nishikawa, H Sako, T Imaizumi, K Yano, K Maemura, N Ashizawa, M Hazama, Y Ishida, T Ito, M Kanda, M Kimura, T Noguchi, Y Oku, S Seto, S Suzuki, H Ogawa, K Goto, K Honjio, Y Horio, H Jinnouchi, Y Kaku, S Kawano, T Kimura, Y Kiyohara, A Maki, N Matsumoto, K Misumi, T Sakamoto, K Sasaki, S Sugiyama, E Tanaka, S Uemura, C Tei, K Arima, Y Daitoku, H Eto, T Hashino, K Ichinari, Y Ikeda, A Iriki, K Kiyonaga, K Kubota, Y Makise, S Masuzaki, M Miyata, H Mizoguchi, T Niiyama, Y Samejima and S Yonezawa. 